Asian J Agric \& Biol. 2021(3). $\mathrm{AJAB}$ DOI: $10.35495 / a j a b .2020 .10 .520$

Original Article

\title{
In vitro anticancer potential of Sacrocephalus latifolius leaves extract and its fractions on human MCF-7 and NCI-H460 cancer cell lines
}

\author{
Ikpefan 0. Emmanuel1 ${ }^{*}$, Ayinde B. Adesina2 ${ }^{2}$ Ikpefan J. Ohonmoimen ${ }^{3}$, Mudassir Azah4, Farooq A. Dar \\ ${ }^{1}$ Department of Pharmacognosy and Traditional Medicine, Delta State University, Abraka, Nigeria \\ ${ }^{2}$ Department of Pharmacognosy, University of Benin, Benin City, Nigeria \\ ${ }^{3}$ Department of Science Laboratory Technology, Faculty of Science, Delta State University, Abraka, Nigeria \\ ${ }^{4}$ Dr. Panjwani Centre for Molecular Medicine and Drug Research, International Centre of Chemical and Biological Sciences, \\ University of Karachi, Karachi, Pakistan \\ ${ }^{5}$ Hamdard A1 - Majeed College of Eastern Medicine, Faculty of Eastern Medicine, Hamdard University, Karachi, Pakistan
}

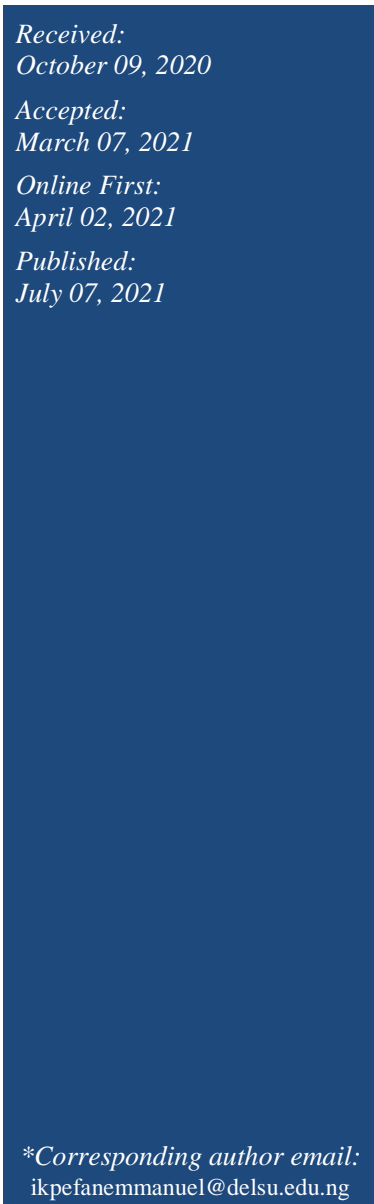

\section{Abstract}

Sacrocephalus latifolius is one of the recipes used in traditional medicine for the treatment of cancer ailment in South-western Nigeria. This work was aimed at evaluating the extract and fractions of this plant against human breast (MCF-7) and lung (NCI-H460) cancer cell lines as well as their antioxidant activity. While the antproliferative assay was done using the SRB-assay for the extract $(1-250 \mu \mathrm{g} / \mathrm{mL})$ and fractions $(1-100 \mu \mathrm{g} / \mathrm{mL})$, the DPPH antioxidant assay was recorded at concentrations between $25-400 \mu \mathrm{g} / \mathrm{mL}$. Against the MCF-7 cell lines, the extract and ethyl acetate fractions recorded growth-inhibitory activities at all concentrations with $\mathrm{GI}_{50}$ of 73.02 and $63.38 \mu \mathrm{g} / \mathrm{mL}$. While the chloroform fraction recorded cytotoxicities of -1.14 and $6.19 \%$ at 50 and $100 \mu \mathrm{g} / \mathrm{mL}$ with $\mathrm{GI}_{50}$ and TGI of 43.18 and $89.70 \mu \mathrm{g} / \mathrm{mL}$, the hexane and aqueous fractions were inactive. Similar pattern of activity was recorded against NCI-H460 cell lines with the chloroform fraction exhibiting a higher sensitivity with $\mathrm{GI}_{50}$ and TGI of 24.12 and $54.50 \mu \mathrm{g} / \mathrm{mL}$ respectively. The antiproliferative activity was further corroborated by the higher antioxidant activity ( $\mathrm{IC}_{50}$ of $17.91 \mu \mathrm{g} / \mathrm{mL}$ ), total phenolic (86.30 mg GAE/g) and flavonoid contents (72.74 $\mathrm{mg}$ QUE/g) of the chloroform fraction. The folkloric use of $S$. latifolius in the treatment of tumor ailments has been justified by this work.

Keywords: Sacrocephalus latifolius, Anti-proliferative, Cytotoxic, MCF-7, NCIH460, DPPH, Antioxidant, SRB-assay

\section{How to cite this:}

Emmanuel IO, Adesina AB, Ohonmoimen IJ, Azah M and Dar FA, 2021. In vitro anticancer potential of Sacrocephalus latifolius leaves extract and its fractions on human MCF-7 and NCI-H460 cancer cell lines. Asian J. Agric. Biol. 2021(3): 202010520. DOI: https://doi.org/10.35495/ajab.2020.10.520

This is an Open Access article distributed under the terms of the Creative Commons Attribution 3.0 License. (https://creativecommons.org/licenses/by/3.0), which permits unrestricted use, distribution, and reproduction in any medium, provided the original work is properly cited.

\section{Introduction}

Cancer, one of the leading cause of death, is a huge public concern worldwide with a rapid predominance in
Africa, Asia and South America (Thun et al., 2010). The treatment of this disease over the years has been the use of chemotherapy (Arruebo et al., 2011a). Unfortunately, this method of treatment has inflicted 
adverse side effects on the human tissues resulting in the inactivation of the bone marrow, vomiting, nausea as well as producing reactive oxygen species or free radicals in the body which causes oxidative stress which causes harm to many cellular components such as DNA, protein and lipid which are related to chronic debilitating diseases such as cancer, hypertention as well as diabetes (Nurgali et al., 2018). The presence of antioxidant helps to mop up these ROS in the body.

The use of plants as an alternative form of treatment for this diseases has been recommended as a result of the less side effects coupled with the abundance of phytochemicals such as the phenolics which they contain, which are capable of inhibiting free radicals causing cancer and other diseases (Sofowora et al., 2013). The search for alternative form of treatment of this disease has open a new horizon in to plant-based research for the discovery of anti-cancer and antioxidant agents (Choudhari et al., 2020).

Sacrocephalus latifolius (Sm.) E. A. Bruce (Rubiaceae) is a plant with diverse medicinal values. It is locally known in some Nigerian speaking tribes as Egbesi, uburu Nbitinu inu and marga in Youruba, Igbo and Hausa tribes respectively. It is found in tropical areas of Africa. It has many irregular branches and thick foliage. The plant is widely distributed in Nigeria and mostly found in the south-east and southsouth regions (Enemor and Okaka, 2013).The antimalaria, antidiabetics (Gidado et al., 2005), and hepatoprotective, (Ngo et al., 2009) have been reported previously on the plant. The plant has been identified as one of the cancer treatment recipes in south-west Nigeria (Soladoye et al., 2010).

While the plant is being recorded as an efficient medicinal plant, the in vitro anticancer studies against lung and breast cancers has never been reported. Our earlier work recorded higher cytotoxic and growthinhibiting effects of the leaves over the root barks of the plant using simple bench-top assay involving the use of the radicles of Sorghum bicolor and tadpole of Raniceps raninus (Ikpefan et al., 2014). The present studies take another look at the in vitro anticancer studies of the leaves extract and fractions against breast and lung cancer cell lines.

\section{Material and Methods}

\section{Collection, processing and extraction of plant sample}

The leaves of Sarcocephalus latifolius were collected in Benin City and identified with the assistance of a botanist. Voucher specimen was sent to Forest Research Institute of Nigeria (F.R.I.N.) Ibadan, after authentication it was deposited under herbarium number (FHI 109707).

The collected leaves samples were air-dried in the laboratory for 3 days, and subsequently in an oven held for 24 hours at $45^{\circ} \mathrm{C}$, during which they were ground to form powder using an electric milling machine in the laboratory (Chris Norris, England). A portion of the powdered sample $(1.5 \mathrm{~kg})$ was extracted with $90 \%$ methanol using the cold maceration method previously described by Osama and Awdelkarim (2015) and the extract obtained was weighed and recorded.

\section{Fractionation of extract}

A portion of the resulting leaves extract $(55.0 \mathrm{~g})$ was immersed in equal volumes of water and methanol (1:1, $400 \mathrm{~mL}$ ) and subjected to hexane, chloroform and ethyl acetate-solvent partitioning in a separating funnel. The fractions were collected, concentrated, and weighed.

\section{Qualitative determination of phytochemicals in the} extract and fractions of $S$. latifolius

The screening of the extract and fractions of $S$. latifolius for the presence of phytochemicals was performed with standard methods.

\section{Cell lines and cell cultures}

The PCMD Molecular Bank of the University of Karachi in Pakistan was the source of the human cancer cell lines MCF-7 (Breast) and NCI-H460 (lung). The cells were cultured and maintained following the guidelines of Geraghty et al. (2014).

\section{Anti-cancer studies of leaves and root barks extract of Securinega virosa}

The antiproliferative activities of the extract and fractions of $S$. latifolius against the cell lines was carried using the SRB-assay method previously described by Shekan and Storeng (1990). Extract and fractional stock solutions of S. latifolius $(40 \mathrm{mg} / \mathrm{mL}$ in DMSO) were prepared and the corresponding dilutions in RPMI-1640 were prepared, consisting of gentamicin $(50 \mathrm{~g} / \mathrm{mL})$ and monolayer trypsinization, determination of cell viability as well as cell counting from the confluent flask $\left(75 \mathrm{~cm}^{2}\right)$ were carried out. Monolayer formation of MCF-7 and NCI-H460 cells $(10,000$ cells / well/100 $\mu \mathrm{L})$ was seeded in a $\mathrm{CO}_{2}$ incubator at $37^{\circ} \mathrm{C}$ and incubated for $24 \mathrm{~h}$. The various 
concentrations of methanol extracts of $S$. latifolius (1, $10,50,100,200$, and $250 \mu \mathrm{g} / \mathrm{mL})$ and fractions $(1,25$, 50, 75 and 100) were added (100 $\mu \mathrm{L} /$ well $)$ in appropriate wells, followed by incubation for $48 \mathrm{~h}$. Appropriate controls and blanks (drug and extract) were also prepared. At the end of $48 \mathrm{~h}$, time zero- $1 \mathrm{CTz}$ 1 plate) and time zero- 2 (Tz 2 plate) cells $(10,000$ cells/well/100 $\mu \mathrm{L}$ for MCF-7 and NCI-H460) were seeded for monolayer formation and incubated in a $\mathrm{CO}_{2}$ incubator at $37^{\circ} \mathrm{C}$ for $24 \mathrm{~h}$.

\section{Determination of total phenolic content}

The Folin Ciocalteu method was used to assess total phenolic content (Chang et al., 2002). Calibration curve was built using standard gallic acid and the total phenolic content is represented as $\mathrm{mg}$ equivalents of gallic acid (GAE)/g dry weight (DW).

\section{Determination of flavonoid content}

The Aluminum chloride colorimetric assay previously described by Chang et al. (2002), was used to test the flavonoid content. The calibration curve was plotted using quercetin standards and the quality of flavonoids was expressed as equivalents of mg quercetin $(\mathrm{QE}) / \mathrm{g}$ DW.

\section{Determination of Antioxidant activity of extract and fractions of $\boldsymbol{S}$. latifolius}

The DPPH antioxidant-RSA for the extract and fractions of $S$. latifolius was performed using Osama and Awdelkarim (2015). Following the procedure, 1 $\mathrm{mL}(0,1 \mathrm{mM})$ of DPPH solution in methanol was mixed in water at various concentrations with $3 \mathrm{~mL}$ of sample solution. At last the absorbance was measured at $517 \mathrm{~nm}$, after $30 \mathrm{~min}$. Diminishing DPPH solution absorbance indicates an increase in DPPH's radicalscavenging activity. The $\mathrm{IC}_{50}$ scavenging assay values (concentration which can achieve 50 percent scavenging) are calculated by plotting the inhibition percentage against the concentration to quantify the activity. The experiment was done in replicate of three.

The radicalscavenging DPPH action was calculated o $\mathrm{n}$ the basis of the following equation:

$\%$ Inhibition $=\left(\mathrm{A}_{0}-\mathrm{A}_{1}\right) / \mathrm{A}_{0} \times 100$.

Where, $\mathrm{A}_{0}$ - the absorbance of the control;

$A_{1}$ - the absorbance of the test samples (extract or fractions).

\section{Statistical analysis}

This was done using GraphPad Prism 7.0 and Oneway analysis of variance (ANOVA) and TukeyKramer Multiple Comparisons test were for the data analysis. The values were finally represented as Mean $\pm(\mathrm{SEM})$.

\section{Results}

Yield of the extract and fractions of S. latifolius

The $1.5 \mathrm{~kg}$ of the extracted powdered leaves of $S$. latifolius yielded $75.15 \mathrm{~g}$ of the extract which is equivalent to $5.00 \%$ yield. Upon partitioning, a total of 2.85, 7.87, 9.08 and $16.60 \mathrm{~g}$ of hexane, chloroform, ethyl acetate and aqueous fractions were recorded which implies $0.19,0.52,0.61$ and $1.24 \%$ yield.

\section{Results of phytochemical screening of extracts and fractions}

The phytochemical screening of the extract and its respective fractions indicated the existence of some secondary metabolites, such as alkaloids, anthraquinones, saponins, terpenes, flavonoids, tannins and cardiac glycosides in different intensities (Table 1)

Table-1. Phytochemical screening results of extract and partitioned fractions of $S$. latifolius

\begin{tabular}{|c|c|c|c|c|c|}
\hline \multirow{2}{*}{$\begin{array}{c}\text { Phytochemical } \\
\text { groups }\end{array}$} & \multirow{2}{*}{ Extract } & \multicolumn{5}{|c|}{ Solvent fractions } \\
\cline { 3 - 6 } & Hexane & Chloroform & $\begin{array}{c}\text { Ethyl } \\
\text { acetate }\end{array}$ & Aqueous \\
\hline Alkaloids & ++ & + & +++ & + & ++ \\
\hline Anthraquinones & + & - & ++ & + & + \\
\hline $\begin{array}{c}\text { Tannins/Phenolic } \\
\text { compounds }\end{array}$ & + & - & ++ & + & + \\
\hline Flavonoids & + & - & ++ & + & - \\
\hline Saponins & ++ & - & ++ & +++ & + \\
\hline $\begin{array}{c}\text { Cardiac } \\
\text { glycosides }\end{array}$ & + & - & + & ++ & ++ \\
\hline Terpenes & + & + & ++ & ++ & + \\
\hline Steroids & + & ++ & + & + & + \\
\hline
\end{tabular}

Key: +++: appreciable amount; ++: moderate amount; $+:$ minute amounts; - : not detected

\section{Results of the effects of the extract and fractions on} MCF-7 and NCI-H460 cell lines

Comparing the anti-proliferative activities of the extract and fractions of $\mathrm{S}$. latifolius against the cell lines, showed a concentration based activities. The extract reported growth-inhibitory activities against MCF-7 cell lines at concentrations between 10-250 $\mu \mathrm{g}$ / $\mathrm{mL}$ with $\mathrm{GI}_{50}$ of $73.02 \mu \mathrm{g} / \mathrm{mL}$. The activity was observed to increase after partitioning as the 
chloroform fraction became more cytotoxic as -1.14 and $-6.12 \%$ cytotoxicities were recorded at 50 and 100 $\mu \mathrm{g} / \mathrm{mL}$ with $\mathrm{GI}_{50}$ and TGI of 43.18 and $89.70 \mu \mathrm{g} / \mathrm{mL}$. The hexane and aqueous fractions were inactive because they reported cell death of less than 50 percent, even at maximum concentrations (Table 2).

The experiment was observed against NCI-H460 cell lines, to follow the same trend as MCF-7. However, the chloroform and ethyl acetate fractions recorded higher sensitivity than that observed with MCF-7 cells. While the ethyl acetate fraction at $100 \mu \mathrm{g} / \mathrm{mL}$ gave cytotoxicity of $-1.72 \%$ as well as $\mathrm{GI}_{50}$ and TGI of 32.05 and $84.50 \mu \mathrm{g} / \mathrm{mL}$, the chloroform fraction at similar concentrations gave cytototoxicity of -16.26 percent and $\mathrm{GI}_{50}$ and TGI of 24.12 and $54.50 \mu \mathrm{g} / \mathrm{mL}$ respectively (Table 3 ).

Table-2. Sensitivities of the extract and fractions of S. latifolius on breast (MCF-7) cancer cell lines

\begin{tabular}{|c|c|c|c|c|c|}
\hline \multirow{2}{*}{$\begin{array}{l}\text { Conc. } \\
(\mu \mathrm{g} / \mathrm{mL})\end{array}$} & \multirow{2}{*}{ Extract } & \multicolumn{4}{|c|}{$\begin{array}{c}\text { Fractions } \\
\% \text { Growth inhibition/cytotoxicity }\end{array}$} \\
\hline & & Hexane & \begin{tabular}{|c|} 
Ethyl \\
acetate
\end{tabular} & Chloroform & Aqueous \\
\hline 1 & - & & $+12.60 \pm 1.02$ & $+53.18 \pm 0.14$ & \multirow{7}{*}{$<50$} \\
\hline 10 & $+21.26 \pm 0.13$ & & $+28.26 \pm 1.22$ & $+64.10 \pm 1.90$ & \\
\hline 50 & $+53.11 \pm 1.49$ & $<50$ & $+63.38 \pm 1.67$ & $-1.14 \pm 0.02$ & \\
\hline 100 & $+62.97 \pm 3.28$ & & $+92.89 \pm 4.09$ & $-6.19 \pm 2.10$ & \\
\hline 200 & $+78.08 \pm 3.01$ & & & & \\
\hline 250 & $+80.97 \pm 1.66$ & & & & \\
\hline $\mathrm{GI}_{50}$ & 73.02 & $>100$ & 63.38 & 43.18 & \\
\hline TGI & $>250$ & $>100$ & $>100$ & 89.70 & $>100$ \\
\hline $\mathrm{LC}_{50}$ & $>250$ & $>100$ & $>100$ & $>100$ & $>100$ \\
\hline
\end{tabular}

Control absorbance at $545 \mathrm{~nm}=1.9 \pm 0.1 \mathrm{n}=3$. Where “+” implies growth inhibition, "-" cytotoxicity, "GI "and "TGI" = concentration causing $50 \%$ and $100 \%$ growth inhibition of cells, while " $\mathrm{LC}_{50}$ " = concentration that killed $50 \%$ cells.

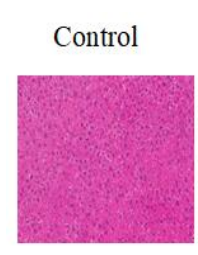

Ethyl acetate fraction

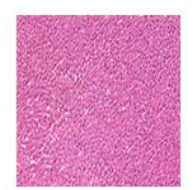

Figure-1. Some photograph showing the morphological distortions of extract and fractions of S. latifolius on MCF-7 cell lines under Inverted microscope (Nikon, objective $8 \times$ )
Table-3. Sensitivities of the extract and fractions of S. latifolius on lung (NCI-H460) cancer cell lines

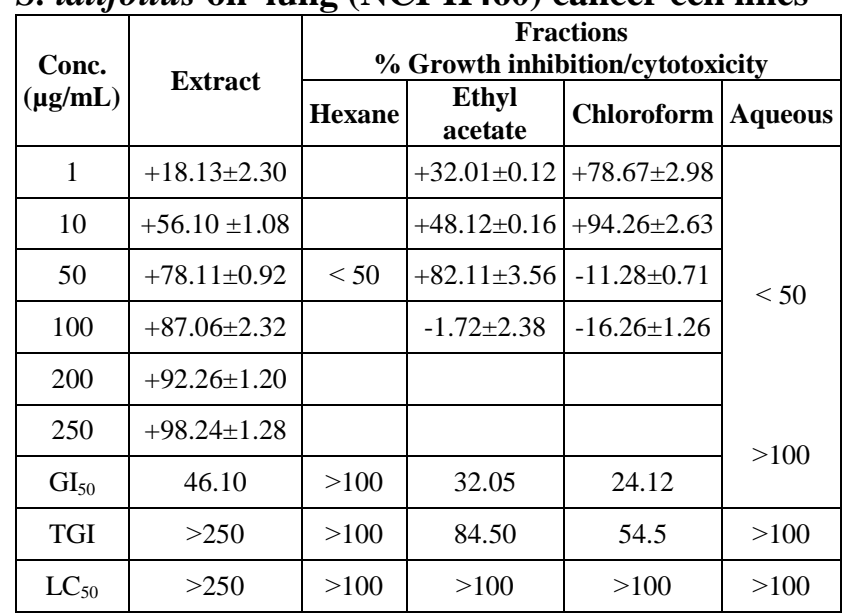

Control absorbance for NCI-H460 in $545 \mathrm{~nm}=2.0 \pm$ $0.1, \mathrm{n}=3$.
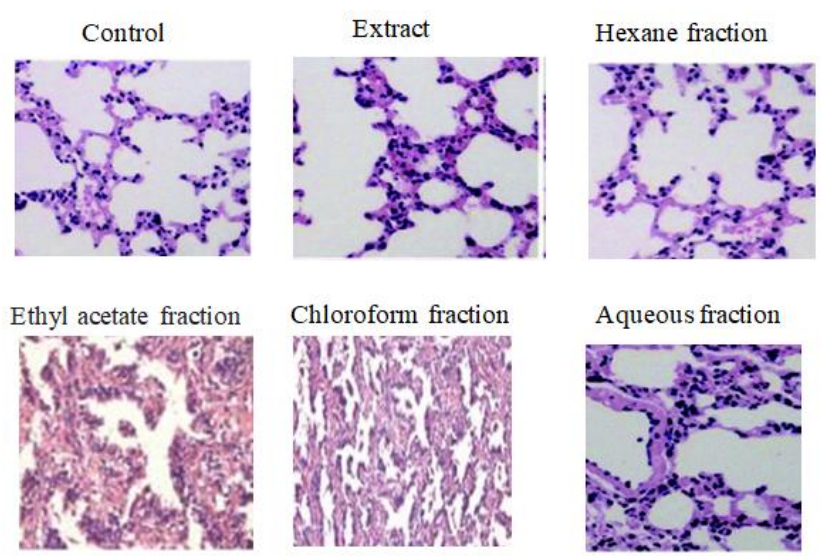

Figure-2. Photograph showing the morphological effects of extract and fractions of $S$. latifolius on NCI-H460 cell lines under inverted microscope (Nikon, objective $8 \times$ )

\section{Result of the evaluation of the total phenolic and} flavonoid contents

Using the equations $(\mathrm{y}=0.0250 \mathrm{x}+0.0009, \mathrm{R} 2=$ $0.980 ; \mathrm{y}=0.022 \mathrm{x}+0.0005, \mathrm{R} 2=0.654)$ the total phenolic and flavonoid content of the S. latifolius extract and fractions was determined using the normal gallic acid and quercetin curve respectively. Among the test samples, the chloroform fraction recorded the highest $(86.30 \pm 0.16 \mathrm{mg} \mathrm{GAE} / \mathrm{g}$ and $72.74 \pm 0.17 \mathrm{mg}$ $\mathrm{QE} / \mathrm{g}$ ) amount of total phenolic and flavonoid content followed by the ethyl acetate fraction $(83.20 \pm 1.01$ $\mathrm{mg} / \mathrm{GAE} / \mathrm{g}$ and $69.49 \pm 2.31 \mathrm{mg} \mathrm{QE} / \mathrm{g}$ ). 
Table-4. Results of the total phenolic and flavonoid contents of the extract and fractions of $S$. latifolius.

\begin{tabular}{|c|c|c|}
\hline Test samples & $\begin{array}{c}\text { Total Phenol } \\
(\mathbf{m g} / \mathbf{G A E} / \mathbf{g})\end{array}$ & $\begin{array}{c}\text { Flavonoid content } \\
(\mathbf{m g} \text { QUE/g) }\end{array}$ \\
\hline Extract & $61.10 \pm 0.07^{\mathrm{a}}$ & $54.11 \pm 0.94^{\mathrm{f}}$ \\
\hline Hexane fraction & $46.72 \pm 1.28^{\mathrm{b}}$ & $31.52 \pm 1.32^{\mathrm{g}}$ \\
\hline Chloroform fraction & $86.30 \pm 0.16^{\mathrm{c}}$ & $72.74 \pm 0.17^{\mathrm{h}}$ \\
\hline Ethyl acetate fraction & $83.20 \pm 1.01^{\mathrm{d}}$ & $69.49 \pm 2.31^{\mathrm{i}}$ \\
\hline Aqueous fraction & $81.11 \pm 2.10^{\mathrm{e}}$ & $52.19 \pm 1.42^{\mathrm{j}}$ \\
\hline
\end{tabular}

Values are mean \pm SEM for triplicate measurements ${ }^{\mathrm{ab}-}$ ${ }^{\mathrm{e}} \mathrm{p}<0.001$, bc-e $\mathrm{p}<0.001$, cd-e $\mathrm{p}>0.05$, d-e $\mathrm{p}>0.05 \mathrm{~ns}$, ${ }^{\mathrm{fg}-\mathrm{i}}$ $\mathrm{p}<0.001,{ }^{\text {i-e }} \mathrm{p}>0.05 \mathrm{~ns}$ (not significant)

Results of DPPH-Antioxidant studies of the extract and fractions of $S$. latifolius

The DPPH-RSA results for the extract and fractions of $S$. latifolius showed variations in activity among the test samples with the chloroform fraction recording the highest RSA-activity corresponding to $\mathrm{IC}_{50}$ of 17.91 $\mu \mathrm{g} / \mathrm{mL}$ which was found lower when compared to that of quercetin $(12.62 \mu \mathrm{g} / \mathrm{mL})$.

Table-5: Results of DPPH-RSA activity of the extract and solvent fractions of $S$. latifolius

\begin{tabular}{|c|c|c|c|c|c|c|}
\hline \multirow[b]{2}{*}{$\begin{array}{c}\text { Conc. } \\
(\mu \mathrm{g} / \mathrm{mL})\end{array}$} & \multirow[b]{2}{*}{ Extract } & \multicolumn{4}{|c|}{ Solvents-solvent fractions } & \multirow[b]{2}{*}{ Quercetin } \\
\hline & & n-hexane & $\begin{array}{l}\text { Ethyl } \\
\text { acetate }\end{array}$ & Chloroform & Aqueous & \\
\hline 25 & $26.10 \pm 1.10$ & $18.20 \pm 2.64$ & $31.01 \pm 1.14$ & $42.50 \pm 2.30$ & $22.11 \pm 3.94$ & $56.25 \pm 4.41$ \\
\hline $\mathbf{5 0}$ & $39.00 \pm 1.06$ & $31.92 \pm 1.97$ & $42.62 \pm 2.92$ & $56.31 \pm 3.78$ & $34.72 \pm 1.64$ & $78.62 \pm 2.36$ \\
\hline 100 & $51.03 \pm 0.12$ & $45.60 \pm 3.21$ & $66.73 \pm 2.92$ & $73.81 \pm 2.56$ & $50.24 \pm 1.65$ & $92.10 \pm 1.62$ \\
\hline 200 & $69.32 \pm 4.19$ & $52.10 \pm 1.92$ & $72.50 \pm 2.33$ & $86.76 \pm 3.92$ & $52.60 \pm 2.05$ & $96.42 \pm 3.76$ \\
\hline 400 & $76.11 \pm 2.50$ & $58.05 \pm 4.01$ & $83.24 \pm 3.11$ & $91.30 \pm 1.94$ & $64.12 \pm 4.00$ & $99.08 \pm 2.53$ \\
\hline $\mathrm{IC}_{50}$ & $87.10^{* *}$ & $88.31^{* *}$ & $63.01^{* *}$ & $17.91^{* *}$ & $151.36^{* *}$ & 12.62 \\
\hline
\end{tabular}

"Significantly different from control (Quercetin) $\mathrm{P}<0.01$

\section{Discussion}

The rising cases of cancer globally and the several side effects associated with the current forms of treatment (chemotherapy, radiation, surgery, etc.) of the disease is of great concern to the international community (Arruebo et al., 2011b).

Medicinal plants have shown significant application in the management of numerous diseases including cancer (Desai et al., 2008). This is as a result of the active principles such as alkaloids, flavonoids, saponins, terpenes which fights against these diseases including cancer. Our study showed the presence of some of these active principles in both the extract and fractions of S. latifolius.

The solvent-solvent partitioning of the extract was necessitated from the fact that the chemical constituents in plant exist in different polarities, hence the hexane, chloroform and ethyl acetate as well as the aqueous fractions are therefore separated into nonpolar, semi-polar and polar phases of the extract respectively. This explains the variation in antiproliferative activity against the cell lines as well as the antioxidant activity. For example, at $100 \mu \mathrm{g} / \mathrm{mL}$, the extract +78.08 and $+87.06 \%$ growth-inhibiting effects on the cell lines (MCF-7 and NCI-H460). The activity later increased and became cytotoxic as the chloroform fraction recorded -6.19 and $-16.26 \%$ cytotoxicities at the same concentration. The chloroform fraction exhibited higher antiproliferative activity followed by the ethyl acetate fraction which is in line with the work of Memariani et al. (2016). The higher sensitivity of NCI-H460 cell lines to the test materials agree with the findings of Al-Oqail et al. (2015) where A-549 lung cancer cells were more sensitive to all the tested extract and fractions of Nepeta deflersiana compared to MCF-7 cells. However, this does not agree with our previous work (Ikpefan et al., 2019).

By nature, plants are foreseeably the largest sources of antioxidants which are protective against several diseases e.g cancer and cardiovascular disease (Zhang et al., 2015). Our studies have shown the extract and fractions of $S$. latifolius to be a rich source of antioxidants. The variation in the total phenolic (TP) and flavonoid (TF) contents among the extract and fractions of $S$. latifolius could accounts for the variations in the antioxidant activities among the test samples. For example, the chloroform fraction which recorded the highest TP $(86.30 \pm 0.16 \mathrm{mg} / \mathrm{GAE} / \mathrm{g})$ and TF (72.74 $\pm 0.17 \mathrm{mg}$ QE/g) also recorded the most effective antioxidant activity having recorded an $\mathrm{IC}_{50}$ of $17.91 \mu \mathrm{g} / \mathrm{mL}$ against the $12.62 \mu \mathrm{g} / \mathrm{mL}$ recorded by quercetin. This pattern of results have previously been reported by Cho et al. (2011) where the chloroform fraction recorded higher phenolic and flavonoid contents as well as antioxidant activity among the other fraction. However, Abdel-Gawad et al. (2014) and Oresanya et al. (2020) have reported higher phenolic, flavonoid content and antioxidant activity of ethyl acetate fraction of six Allium species and Musa acuminate fruits and leaves. The therapeutic activity of plants is mainly due to polyphenolic metabolites, especially the flavonoids and phenolic contents. Our 
results showed a higher reduction in cell growth in the MCF-7 and NCI-H460 cancer cell lines as well as the DPPH-antioxidant activity of the of the chloroform fraction of $S$. latifolius. The higher phenolic and flavonoid contents in the chloroform fraction could be responsible for the antiproliferative activities recorded, hence could serve as a potential source of anticancer agents.

\section{Conclusion}

Our results have demonstrated a considerable antiproliferative and antioxidant potentials of the leaves of S. latifolius and the activities reside more in its chloroform fraction. This further justifies the folkloric use of this plant as one of the recipes used by some Nigerian herbalist in treating cancer patients. However, isolation of the active compounds and in vivo antiproliferative studies involving the use of other cell lines as well as their mode of action will form the basis of the next phase of the work.

Disclaimer: None.

Conflict of Interest: None.

Source of Funding: Non Align Movement for Science \& Technology Centre (NAM S \& T)

\section{References}

Abdel-Gawad M, Abdel-Aziz M, El-Sayed M, ElWakil E and Abdel-Lateef E, 2014. In vitro antioxidant, total Phenolic and flavonoid contents of six Allium species growing in Egypt. J. Microbiol. Biotechnol. Food Sci. 3(4): 343-346.

Al-Oqail MM, Al-Sheddi ES, Siddiqui MA, Musarrat J, Al-Khedhairy AA and Farshori NN, 2015. Anticancer Activity of Chloroform Extract and Sub-fractions of Nepeta deflersiana on Human Breast and Lung Cancer Cells: An In vitro Cytotoxicity Assessment. Pharmacogn. Mag. 11(Suppl 4): S598-S605.

Arruebo M, Vilaboa N, Sáez-Gutierre B, Lambea J, Tres A, Valladares M and González-Fernández A, 2011a. Assessment of the evolution of cancer treatment therapies. Cancers. 3(3):3279-3330.

Arruebo M, Vilaboa N, Sáez-Gutierrez B, Lambea J, Tres A, Valladares M and González-Fernández A, 2011b. Assessment of the evolution of cancer treatment therapies. Cancers. 3(3):3279-3330.
Chang C, Myang M, Wen H and Chern J, 2002. Estimation of total flavonoid content in propolis by two complementary colometric methods. J. Food Drug. Anal. 10(3):178-182

Cho M, Lee HS, Kang IJ, Won MH and Yo U, 2011. Antioxidant properties of extract and fractions from Enteromorpha prolifera, a type of green seaweed. Food Chem. X. 127(3): 999-1006.

Choudhari AS, Mandave PC, Deshpande M, Ranjekar $\mathrm{P}$ and Prakash O, 2020. Phytochemicals in Cancer Treatment: From Preclinical Studies to Clinical Practice. Front. Pharmacol. 10:1614-628

Desai AG, Qazi GN, Ganju RK, El-Tamer M, Singh J, Saxena AK, Bedi YS, Taneja SC and Bhat HK, 2008. Medicinal plants and cancer chemoprevention. Curr. Drug Metab. 9(7):581591.

Enemor VHA and Okaka ANC, 2013. Sub-acute Effects of Ethanol Extract of Sarcocephalus latifolius Root on Some Physiologically Important Electrolytes in Serum of Normal Wistar Albino Rats. Pakistan Journal of Biological Sciences, 16: 1811-1814.

Geraghty RJ, Capes-Davis A, Davis JM, Downward J, Freshney RI, Knezevic I, Lovell-Badge R, Masters JRW, Meredith J, Stacey GN, Thraves P and Vias M, 2014. Guidelines for the use of cell lines in biomedical research. Br J Cancer. 111(6): 1021-1046.

Gidado A, Ameh DA and Atawodi SE, 2005. Effect of Nauclea latifolia leaves aqueous extract on blood glucose levels of normal and alloxan-induced diabetic rats. Afr. J. Biotechnol. 4: 91-93.

Ikpefan EO, Ayinde BA, Mudassir A and Farooq AD, 2019. Comparative In Vitro Assessment of the Methanol Extracts of the Leaf, Stem, and Root Barks of Cnidoscolus aconitifolius on Lung and Breast Cancer Cell Lines. Turk. J. Pharm. Sci. 16(4):375-379.

doi: 10.4274/tjps.galenos.2018.19942.

Ikpefan EO, Ayinde BA and Adedokun AO, 2014. Comparative phytochemical, cytotoxic and growth inhibitory effects of the leaf and root barks of Sarcocephalus latifolius (J.E. Smith) E.A. Bruce (Rubiaceae). Intl. J. Biosci. 4(4):162-168.

Memariani T, Hosseini T, Kamali H, Mohammadi A, Ghorbani M, Shakeri A and Shahsavand S, 2016. Evaluation of the cytotoxic effects of Cyperus longus extract, fractions and its essential oil on the PC3 and MCF7 cancer cell lines. Oncol. Lett. 11:1353-1360. 
Ikpefan O. Emmanuel et al.

Ngo BE, Taïwe GS, Moto FCO, Ngoupaye GT, Nkantchoua GN, Pelanken MM, Rakotonirina SV and Rakotonirina A, 2009. Anticonvulsant, anxiolytic and sedative properties of the roots of Nauclea latifolia Smith in mice. Epilepsy Behav. 15: 434-440.

Nurgali K, Jagoe RT and Abalo R, 2018. Editorial: Adverse Effects of Cancer Chemotherapy: Anything New to Improve Tolerance and Reduce Sequelae?. Front. Pharmacol. 9:245-254

Oresanya IO, Sonibare MA, Gueye B, Balogun FO, Adebayo S, Ashafa A and Morlock G, 2020. Isolation of flavonoids from Musa acuminata Colla (Simili radjah, ABB) and the in vitro inhibitory effects of its leaf and fruit fractions on free radicals, acetylcholinesterase, 15lipoxygenase, and carbohydrate hydrolyzing enzymes. J. Food Biochem. 44(3): e13137.

Osama A and Awdelkarim S, 2015. Phytochemical screening of Ficus sycomorus L. bark and Cleome gynandra L. aerial parts. J. Pharmacogn. Phytochem. 4(4):24-27

Shekan P and Storeng R, 1990. New colorometric cytotoxicity assay for anticancer drug screening. J. Natl. Cancer Inst. 82: 1107-1112

Sofowora A, Ogunbodede E and Onayade A, 2013. The role and place of medicinal plants in the strategies for disease prevention. Afr. J. Tradit. Complement. Altern. Med. 10(5):210-229.

Soladoye MO, Amusa NA, Raji-Esan SO, Chukwuma EC and Taiwo AA, 2010. Ethnobotanical survey of anti-cancer plants in Ogun State, Nigeria. Ann. Biol. Res. 1: 261-273.
Thun MJ, DeLancey JO, Center MM, Jemal A and Ward EM, 2010. The global burden of cancer: priorities prevention. Carcinogenesis. 31(1):100-110

Zhang YJ, Gan RY, Li S, Zhou Y, Li AN, Xu DP and Li HB, 2015. Antioxidant Phytochemicals for the Prevention and Treatment of Chronic Diseases. Molecules. 20(12):21138-21156.

\section{Contribution of Authors}

Emmanuel IO: Conceived concept, research methodology developed, data collection, literature review, data analysis, final reading and acceptance of manuscripts.

Adesina AB: Principal overseer. Supervised compilation of data, literature review, data processing, final reading and acceptance of manuscripts.

Ohonmoimen IJ: Participated actively in the extraction and fractionation of the extract, proof reading, final reading and endorsement of manuscripts.

Azah M: Design the anticancer methodology and cell culture study and analyzing of data.

Dar FA: Co-supervised the anticancer study. 